\title{
5. PHOSPHATES AND GLAUCONITES OF SITES 798 AND 799 1
}

\author{
Karl B. Föllmi² and Marta von Breymann ${ }^{3}$
}

\begin{abstract}
Glauconites and phosphates have been detected in almost all investigated samples at Sites 798 (uppermost Miocene or lower Pliocene to Pleistocene) and 799 (early middle Miocene to Pleistocene). Autochthonous occurrences appear in very minor quantities (generally below $0.2 \%$ ) throughout the drilled sequences, whereas allochthonous accumulations are limited to the lower Pliocene or uppermost Miocene sequence at Site 798 (glauconites) and to the upper and middle Miocene sequence at Site 799 (upper and middle Miocene: glauconites; middle Miocene: phosphates). X-ray fluorescence, microprobe, and bulk chemical analyses indicate high variabilities in cations and anions and generally low oxide totals. This is probably related to the substitution of phosphate and fluoride anions by hydroxide and carbonate anions in phosphates and to the depletion of iron, aluminum, and potassium cations and the enrichment in hydroxide and crystal water in glauconites. Gradients in pore-water contents of dissolved phosphate and fluoride at Sites 798 and 799 suggest a depth of phosphate precipitation between 30 and 50 mbsf, with fluoride as the limiting element for phosphate precipitation at Site 798. Phosphate and fluoride appear to be balanced at Site 799.

Crude extrapolations indicate that the Japan-Sea sediments may have taken up approximately $7.2 \times 10^{10} \mathrm{~g} \mathrm{P}_{\text {total }} / \mathrm{yr}$ during the Neogene and Pleistocene. This amount corresponds to approximately $0.3 \%$ of the estimated present-day global transfer of phosphorus into the sediments and suggests that the Japan Sea constitutes an average sink for this element. The two main carriers of phosphorus into the present Japan Sea are the Tshushima and the Liman currents, importing approximately $6.6 \times 10^{10} \mathrm{~g} \mathrm{P}$ and $5.7 \times 10^{10} \mathrm{~g} \mathrm{P}$ per year, respectively. Bulk chemical analyses suggest that at least $36 \%$ of $\mathrm{P}_{\text {total }}$ in the sediments is organically bound phosphorus. This rather high value, which corresponds to the measured Japan-Sea deep-water $\mathrm{P}_{\text {organic }} / \mathrm{P}_{\text {total }}$ ratios, probably reflects rapid transport of organic phosphorus into the depth of the Japan Sea.
\end{abstract}

\section{INTRODUCTION}

In contrast to shelf phosphorites, occurrences of phosphates in oceanic sediments have generally been poorly documented and are only recently subjected to more intense quantitative research (Froelich et al., 1982; Cook, 1984; Baturin, 1988; Ingall et al., 1990; Berner et al., in press). Their analyses suggest that deep-water sedimentary phosphates are ubiquitous but do not exceed $0.5 \mathrm{wt} \%$ of the average oceanic sediments. Based upon their large size, oceanic sedimentary reservoirs may, therefore, constitute a significant sink for phosphorus, which probably surpasses the shell sinks in importance. Evaluations of the nature and quantity of buried phosphorus-containing phases at oceanic sites, such as the ones drilled during ODP Leg 128 (Japan Sea) may help to further constrain the role of oceanic sediments as reservoirs of phosphorus. These studies may contribute to a more profound understanding of the impact of deep-ocean sediments on the global phosphorus cycle in terms of oceanic residence times and the sensitivity of the phosphorus cycle toward global changes.

Autochthonous glauconites are excellent indicators of shelf and proximal slope environments in which iron and potassium-rich phases are accumulating at slow rates (Odin and Matter, 1981; Van Houten and Purucker, 1984, 1985; Odin and Fullagar, 1988). The presence of glauconite-bearing to glauconite-rich beds and layers both at Site 798 (present water depth: $902 \mathrm{~m}$ ), as well as at Site 799 (present water depth: $2073 \mathrm{~m}$ ), has, for these reasons, implications for the reconstruction of paleoceanographic conditions at that time. Site 798 was drilled in a small depression on top of a presently isolated ridge in the southeast of the Japan Sea; Site 799 is located within a failed rift system — the Kita-Yamato Trough in the central part of the Japan Sea (Ingle, Suyehiro, von Breymann, et al., 1990).

'Pisciotto, K. A., Ingle, J. C., Jr., von Breymann, M. T., Barron, J., et al., 1992. Proc. ODP, Sci. Results, 127/128. Pt. 1: College Station, TX (Ocean Drilling Program).

${ }^{2}$ Geological Institute, ETH-Center, CH-8092 Zürich, Switzerland.

${ }^{3}$ Ocean Drilling Program, Texas A\&M University, 1000 Discovery Drive, College Station, TX 77845-9547, U.S.A.

\section{PHOSPHATIC PARTICLES AT SITES 798 AND 799}

\section{Occurrence}

Minor amounts $(<<1 \%)$ of small phosphate particles $(0.02-$ $0.45 \mathrm{~mm})$, lenticles and phosphate-rich zones $(0.4-1.5 \mathrm{~mm})$ have been observed in all 61 investigated samples throughout the drilled sequences of Sites 798 and 799 (Pl. 1 and 2). In the Pleistocene segments, they occur both within the dark-colored, organic-rich units, as well as in the light-colored units rich in terrigenous detritus (Föllmi, Cramp, et al., this volume). In the Pliocene and Miocene segments of the drilled sections, they have been identified in all major lithologies; biosiliceous clays, porcelanites, and diagenetic carbonates (Griffin and Lindsley-Griffin, this volume).

\section{Character of the Phosphate Particles}

According to their location, association with surrounding sediments, and morphology, the observed phosphate phases have been classified into pristine ( $=$ in situ) and allochthonous occurrences. Pristine phosphates are phosphates that formed at their present location and lack signs of any reworking. They are recognized by their exclusive association with non-event sediments, their lack of sizeand particle sorting, irregular surfaces (may also be spherical), and in some cases, by poorly defined peripheries and transitional zones into adjacent nonphosphatic sediments. Pristine phosphates occur as particles, lenticles (= inpersistent laminae), laminae, and beds.

Allochthonous phosphates result from reworking and transport after phosphate genesis. They may be recognized by their occurrence in event sediments such as turbidites and by particle sorting, particle rounding, and fracturing. They occur as particles, commonly in association with reworked nonphosphatic particles (Föllmi et al., 1991; Föllmi and Garrison, 1991).

Three classes of pristine particles have been identified (Pl. 1 and 2):

1. $0.025-0.01 \mathrm{~mm}$, pale brown, bright reddish brown, and dark brown, homogeneous and isotropic particles (Pl. 1, Fig. 1, and Pl. 2, Fig. 2). These phosphatic particles are characterized by their irregular to almost spherical boundaries, by a random distribution (single 

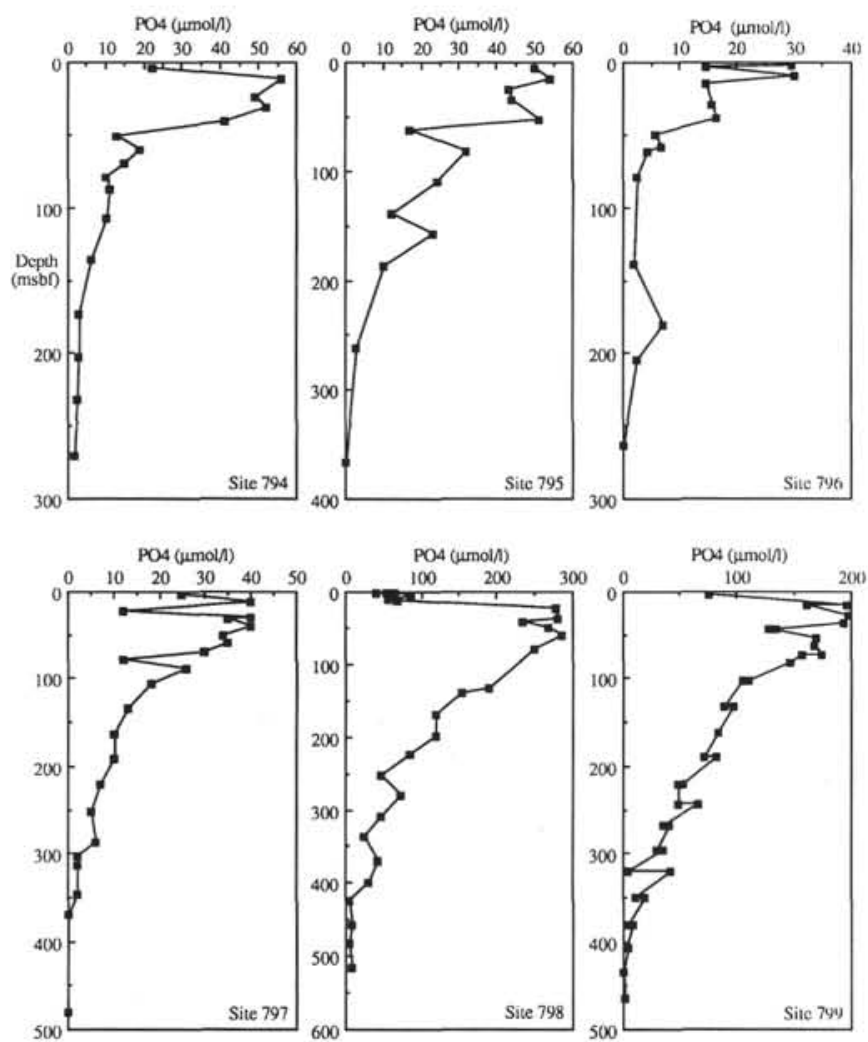

Figure 1. Dissolved $\mathrm{PO}_{4}$ values in pore waters of Sites 794 through 799.

particles disseminated throughout the host sediments, no concentrations observed), and by the lack of any internal structure. They have been observed in almost all sampled non-event sediments.

2. Phosphatized and phosphate-rimmed micro-organisms (maximum $0.8 \mathrm{~mm}$; Pl. 1, Fig. 1), which show internal and external phosphate accretionary rims and/or the replacement of hard and soft parts by phosphate. Phosphate-bearing fossils are generally rare in the inspected samples; preferences in occurrence in terms of lithology and time have not been observed (cf. Griffin and Lindsley-Griffin, this volume).

3. Small lenticular or irregular phosphatic zones and phosphatic tenses (0.4-1.5 mm width, 0.05-0.4 mm thick; Pl. 1, Figs. 3-5). These types of pristine phosphates have been observed in the middle and lower upper Miocene sequence of Hole 799B, commonly within porcelaneous and carbonate-rich claystones. The phosphate-rich

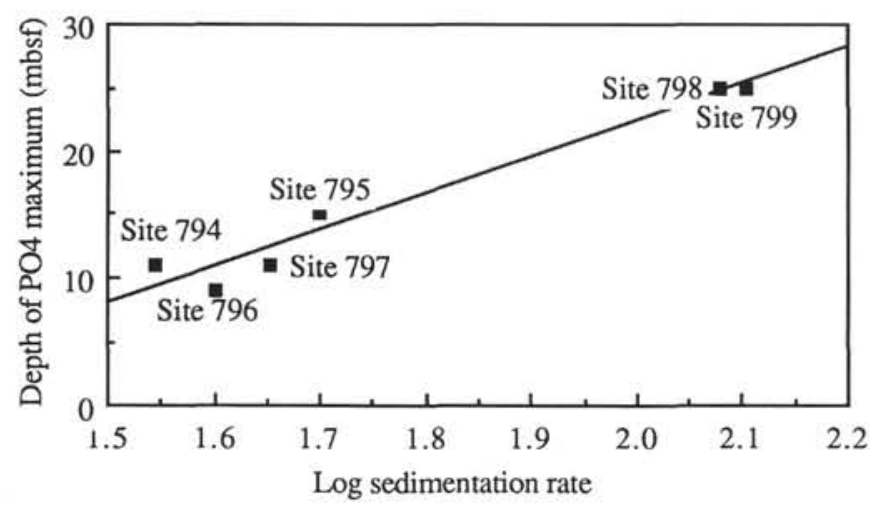

Figure 2. Correlation of depth of pore-water $\mathrm{PO}_{4}$ maxima and sedimentation rates.

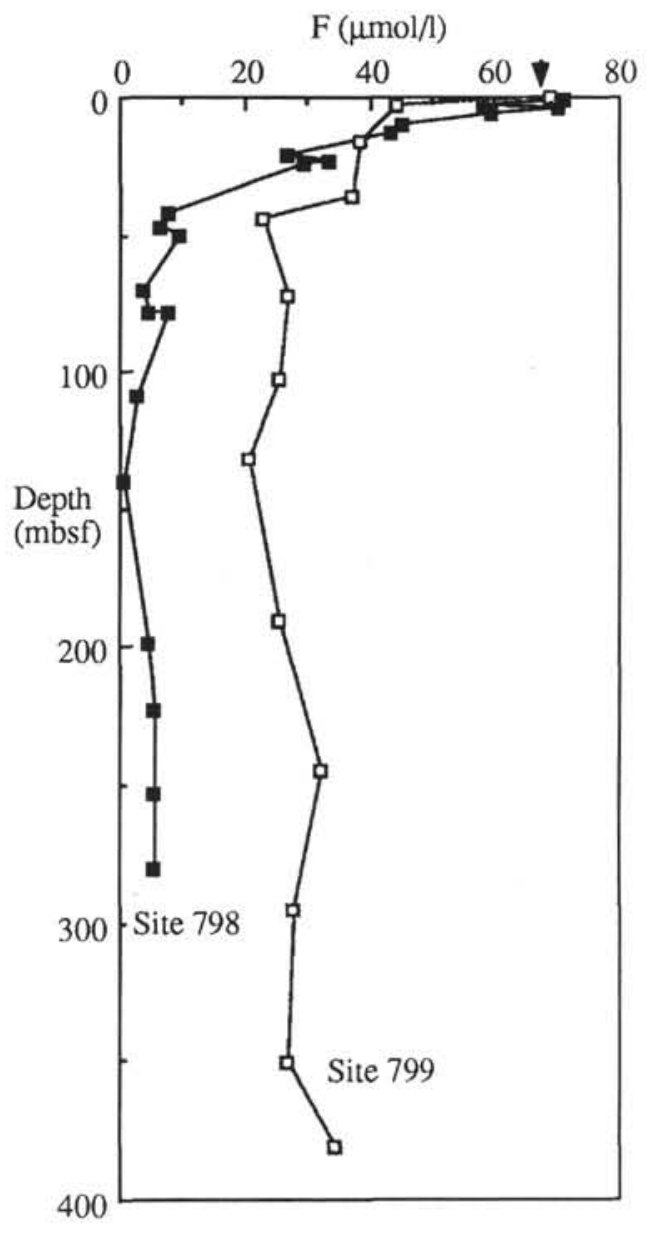

Figure 3. Dissolved fluoride values in pore waters from Sites 798 (solid symbols) and 799 (open symbols). Arrow at top indicates seawater fluoride concentration (68.4 $\mu$ mol; Froelich et al., 1983).

zones have a tendency to cluster along horizontal siliceous veins, which may be interpreted as compaction veins (cf. Griffin and Lindsley-Griffin, this volume). The veins may have functioned as conduits for dissolved phosphate during the formation of the pristine phosphates.

Allochthonous phosphate particles appear to be restricted to the middle Miocene sequence of Hole 799B (Pl. 1, Figs. 6-8). They are commonly well-rounded, range in size between 0.05 and $0.4 \mathrm{~mm}$, and occur in conjunction with siliciclastic and glauconitic particles in event beds. These particles are either lacking significant internal structures (Pl. 1, Figs. 7 and 8), or exhibit a vermiculate texture (PI. 1, Fig. 6), which may be related to a microbial origin (e.g., Krajewski, 1984).

\section{X-Ray Fluorescence, Bulk Chemistry, and Microprobe Analyses}

The $\mathrm{P}_{2} \mathrm{O}_{5}$ values, as determined by $\mathrm{X}$-ray fluorescence analyses of 22 samples from the Pleistocene sequence in Hole 798C, do not exceed 0.15 wt\% (Föllmi, Cramp, et al., this volume). Shipboard $\mathrm{X}$-ray fluorescence analyses of six samples from the Pliocene section in Hole 798B give a maximum $\mathrm{P}_{2} \mathrm{O}_{5}$ value of $0.11 \mathrm{wt} \%$, and 12 samples from the Pliocene and upper, and middle Miocene sections in Holes 799A and 799B show maximum $\mathrm{P}_{2} \mathrm{O}_{5}$ values of $0.17 \mathrm{wt} \%$ (Ingle, Suyehiro, von Breymann, et al., 1990, pp. 151, 293). $P_{\text {total }}$ values determined by bulk chemical analyses in 30 selected samples from Holes 798B, 799A, and 799B remain below $0.26 \mathrm{wt} \%$ (Table 1). 

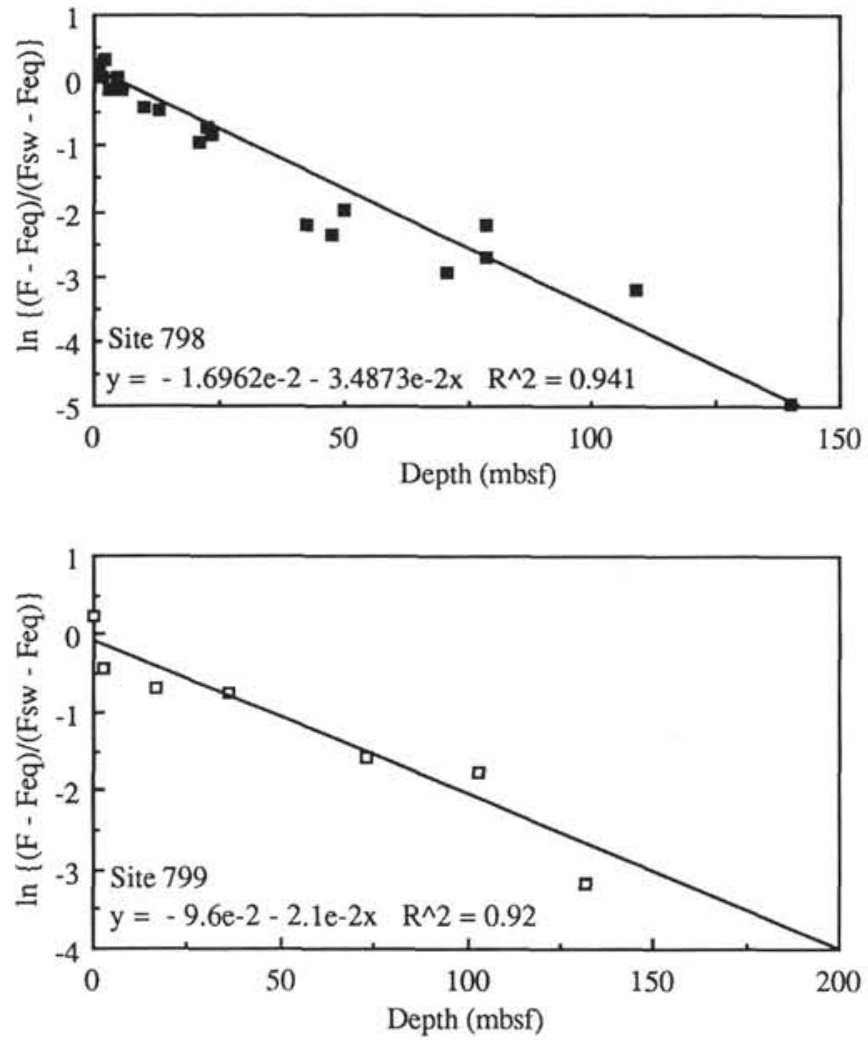

Figure 4. Fluoride-uptake rates vs. sediment depth. $\mathrm{F}=$ fluoride pore-water concentration; $F_{\mathrm{sw}}=$ seawater fluoride; $\mathrm{F}_{\mathrm{eq}}=$ asymptotic fluoride concentration deep in core (Froelich et al., 1983).

These maximum values are in accordance with smear-slide and thin-section inspections, and probably reflect overall tendencies in the recovered cores from the Japan Sea.

Organically bound phosphorus was determined as the difference between the phosphorus extracted from a subsample ignited at $500^{\circ}$ $\mathrm{C}$ for $2 \mathrm{hr}$ and the phosphorus extracted from a nonignited subsample, according to the technique of Aspila, et al. (1976) (Table 1). These results give us a measure of "refractory" phosphorus, which is still incorporated in organic matter and survived diagenetic degradation, relative to phosphates absorbed on clay, iron, and manganese minerals, as well as mineralized phosphates (e.g., Berner et al., in press). The obtained ratios of $\mathrm{P}_{\text {org }} / \mathrm{P}_{\text {inorg }}$ are not linearly correlatable to the measured $\mathrm{C}_{\text {org }}$ contents. This probably depends on the character of the organic matter, which may include various amounts of terrestrial, refractory compounds (McEvoy et al., this volume), as well as on the degree of organic matter degradation, on local conditions of phosphate mineralization, and the quantity of detrital phosphates.

We used a Cameca SX 50 microprobe for the positive identification of a representative set of phosphate particles (Table 2 and Pl. 1 and 2). Values of $\mathrm{P}_{2} \mathrm{O}_{5}$ vary between 14.2 and $34.2 \mathrm{wt} \%$; $\mathrm{CaO}$ values range from 18.9 to $44.2 \mathrm{wt} \%$ and fluoride values from 0.9 to $3.9 \mathrm{wt} \%$. According to these ranges, most phosphate particles may represent francolite, a calcium-fluor apatite. Francolite is characterized by its large variability in composition due to the large amount of substitution possibilities (e.g., Nathan, 1984). The low oxide totals obtained probably reflect the presence of carbonate and hydroxide groups substituting for the phosphate and fluoride anions. In addition, the presence of crystal water and organic matter in the inhomogeneous aggregates of crystallites in francolite may add to the low measured values of total oxides (Nathan, 1984). Low total oxide values correspond to lowered values of all three main constituents of francolite: $\mathrm{CaO}, \mathrm{P}_{2} \mathrm{O}_{5}$, and fluoride (e.g., Sample 128-799B-45R-2, 38-40 cm;
Pl. 1, Fig. 7). In general, higher total oxide values were measured in the detrital phosphates, the pristine zonal and lenticular phosphates, and the phosphatized fossils. In contrast, the pristine homogeneous bright reddish brown to dark brown particles show lower total-oxide values. This is probably due to formation of these different phosphate phases at different stages of diagenesis and the availability of various anions at each given stage. However, a considerable variance was found within single, as well as in similar particles; for instance, in the pristine phosphate-rich zone from Sample 128-799B-6R-1, 106-109 $\mathrm{cm}$, the oxide totals from three different pristine particles differ by 26 wt\% (Pl. 1, Figs. 4 and 5, and Table 2). Large differences are also observed in similar detrital phosphate particles of Sample 128-799B$55 \mathrm{R}-1,139-141 \mathrm{~cm}$. This is consistent with the notion that francolite consists of a chemically inhomogeneous aggregate of crystallites (Nathan, 1984).

\section{Pore-Water Analyses}

Dissolved pore-water phosphate was analyzed aboard JOIDES Resolution following the procedures described by Gieskes and Peretsman (1986). All samples from Sites 127 and 128 show an initial increase in dissolved pore-water phosphate, which is followed by a gradual depletion (Fig. 1; Ingle, Suyehiro, von Breymann, et al., 1990; Tamaki, Pisciotto, Allan, et al., 1990). The depth of the phosphate maxima correlates well with the calculated sedimentation rates, in accordance with the interaction among phosphate diffusion rate of organic matter decomposition and sedimentation rates described by Berner (1980) (Fig. 2). Pore waters of Sites 798 and 799 include the highest levels of dissolved phosphate, with maxima near $200 \mu \mathrm{mol} / \mathrm{L}$ at Site 799 and $300 \mu \mathrm{mol} / \mathrm{L}$ at Site 798 . These levels exceed the postulated threshold value for francolite precipitation

Table 1. Phosphate bulk chemical analyses of selected Leg 128 samples.

\begin{tabular}{|c|c|c|c|c|c|c|}
\hline $\begin{array}{l}\text { Core, Section } \\
\text { Interval }(\mathrm{cm})\end{array}$ & $\begin{array}{l}\text { Depth } \\
\text { (mbsf) }\end{array}$ & $\begin{array}{c}\text { Organic } \\
C(w t \%)\end{array}$ & $\begin{array}{l}\text { Organic } \\
\mathrm{P}(\mathrm{ppm})\end{array}$ & $\begin{array}{l}\text { Inorganic } \\
\mathrm{P}(\mathrm{ppm})\end{array}$ & $\begin{array}{c}\text { Total } \\
\text { P(ppm) }\end{array}$ & $\begin{array}{r}\mathrm{C} / \mathrm{P} \\
\text { ratio }\end{array}$ \\
\hline \multicolumn{7}{|l|}{ 128-798B- } \\
\hline IH-2, 35-41 & 1.85 & 3.42 & 418 & 870 & 1288 & 211 \\
\hline IH- $4,125-131$ & 5.75 & 3.49 & 1161 & 1095 & 2256 & 78 \\
\hline $2 \mathrm{H}-1,45-51$ & 9.85 & 1.86 & 761 & 1158 & 1919 & 63 \\
\hline $2 \mathrm{H}-3,45-51$ & 12.85 & 2.01 & 1072 & 1116 & 2188 & 48 \\
\hline $4 \mathrm{H}-7,56-61$ & 36.96 & 1.84 & 653 & 1239 & 1891 & 73 \\
\hline $5 \mathrm{H}-4,140-150$ & 42.70 & 1.77 & 651 & 1320 & 1971 & 70 \\
\hline $6 \mathrm{H}-4,45-55$ & 50.37 & 1.81 & 427 & 933 & 1360 & 109 \\
\hline $8 \mathrm{H}-4,140-150$ & 70.67 & 1.27 & 402 & 1298 & 1700 & 82 \\
\hline $9 \mathrm{H}-3,123-133$ & 78.57 & 1.07 & 646 & 1205 & 1851 & 43 \\
\hline $14 \mathrm{H}-7,123-133$ & 133.13 & 1.06 & 687 & 1120 & 1807 & 40 \\
\hline $18 \mathrm{H}-6,25-35$ & 169.47 & 0.96 & 654 & 893 & 1547 & 38 \\
\hline $21 X-6,140-150$ & 198.16 & 1.64 & 303 & 1255 & 1559 & 139 \\
\hline $27 X-3,105-115$ & 252.59 & 2.37 & 825 & 1630 & 2456 & 74 \\
\hline $30 X-2,140-150$ & 279.94 & 1.39 & 1136 & 1157 & 2293 & 32 \\
\hline $33 \mathrm{X}-3,140-150$ & 309.65 & 1.92 & 473 & 695 & 1168 & 105 \\
\hline $39 X-4,140-150$ & 369.50 & 1.28 & 615 & 911 & 1526 & 54 \\
\hline $42 X-5,140-150$ & 398.85 & 1.21 & 573 & 1002 & 1574 & 55 \\
\hline $45 X-3,140-150$ & 424.75 & 0.92 & 504 & 764 & 1269 & 47 \\
\hline \multicolumn{7}{|l|}{$128-799$ A- } \\
\hline $1 \mathrm{H}-1,44-49$ & 0.44 & 1.28 & 1080 & 881 & 1961 & 31 \\
\hline $3 \mathrm{H}-2,10-15$ & 12.30 & 0.71 & 799 & 1113 & 1912 & 23 \\
\hline $5 \mathrm{H}-2,20-25$ & 31.60 & 0.38 & 635 & 1199 & 1835 & 15 \\
\hline $7 \mathrm{H}-2,40-45$ & 51.00 & 0.57 & 617 & 1227 & 1843 & 24 \\
\hline $9 \mathrm{H}-2,30-15$ & 70.10 & 1.09 & 674 & 1358 & 2032 & 42 \\
\hline $11 \mathrm{H}-2,20-25$ & 89.20 & 0.41 & 377 & 1161 & 1538 & 28 \\
\hline $17 \mathrm{H}-4,40-45$ & 150.40 & 1.67 & 626 & 1217 & 1843 & 69 \\
\hline $20 \mathrm{H}-4,20-25$ & 179.20 & 0.96 & 187 & 908 & 1095 & 132 \\
\hline $45 X-2,44-49$ & 405.84 & 0.67 & 541 & 1292 & 1834 & 32 \\
\hline \multicolumn{7}{|l|}{ 128-799B- } \\
\hline $28 \mathrm{R}-3,40-45$ & 705.50 & 1.96 & 699 & 1445 & 2144 & 72 \\
\hline $49 \mathrm{R}-1,48-52$ & 904.68 & & 815 & 1705 & 2521 & \\
\hline $62 R-2,13-17$ & 1031.13 & 2.14 & 465 & 1222 & 1687 & 119 \\
\hline Mean value & & 1.49 & 649 & 1146 & 1796 & 67 \\
\hline
\end{tabular}


Table 2. Microprobe analyses of selected phosphate particles from Leg 128. Analyses have been performed on single particles (no replicates).

\begin{tabular}{|c|c|c|c|c|c|c|c|c|c|}
\hline & $\begin{array}{c}-798 \mathrm{~B}-51 \mathrm{X}-6 \\
101-105 \mathrm{~cm}\end{array}$ & $\begin{array}{c}-799 \mathrm{~A}-41 \mathrm{X}-6 \\
144-150 \mathrm{~cm}\end{array}$ & $\begin{array}{l}-799 \mathrm{~B}-6 \mathrm{R}-1 \\
106-109 \mathrm{~cm}\end{array}$ & $\begin{array}{l}-799 \mathrm{~B}-6 \mathrm{R}-1 \\
106-109 \mathrm{~cm}\end{array}$ & $\begin{array}{c}-799 \mathrm{~B}-27 \mathrm{R}-1, \\
58-62 \mathrm{~cm}\end{array}$ & $\begin{array}{c}-799 \mathrm{~B}-45 \mathrm{R}-1 \\
130-133 \mathrm{~cm}\end{array}$ & $\begin{array}{c}-799 \mathrm{~B}-45 \mathrm{R}-2 \\
38-40 \mathrm{~cm}\end{array}$ & $\begin{array}{c}-799 \mathrm{~B}-45 \mathrm{R}-2 \\
38-40 \mathrm{~cm}\end{array}$ & $\begin{array}{c}-799 \mathrm{~B}-45 \mathrm{R}-2 \\
38-40 \mathrm{~cm}\end{array}$ \\
\hline $\mathrm{CaO}$ & 30.7 & 31.0 & 29.5 & 44.2 & 44.2 & 31.6 & 29.2 & 27.4 & 20.0 \\
\hline $\mathrm{TiO}_{2}$ & 0.1 & 0.0 & 0.0 & 0.0 & 0.0 & 0.0 & 0.0 & 0.0 & 0.1 \\
\hline $\mathrm{P}_{2} \mathrm{O}_{5}$ & 20.4 & 18.4 & 24.4 & 33.3 & 32.6 & 21.5 & 22.9 & 20.0 & 15.4 \\
\hline $\mathrm{SO}_{3}$ & 4.9 & 2.8 & 2.6 & 0.7 & 1.6 & 3.1 & 4.1 & 4.3 & 5.3 \\
\hline $\mathrm{K}_{2} \mathrm{O}$ & 0.0 & 0.2 & 0.0 & 0.0 & 0.0 & 0.1 & 0.1 & 0.0 & 0.0 \\
\hline $\mathrm{BaO}$ & 0.1 & 0.0 & 0.1 & 0.0 & 0.0 & 0.0 & 0.0 & 0.1 & 0.0 \\
\hline $\mathrm{ClO}$ & 0.6 & 0.3 & 0.4 & 0.2 & 0.3 & 0.4 & 0.4 & 1.1 & 1.0 \\
\hline $\mathrm{FeO}$ & 1.1 & 0.2 & 0.5 & 0.7 & 0.3 & 0.1 & 1.6 & 2.6 & 2.7 \\
\hline $\mathrm{MnO}$ & 0.5 & 1.9 & 0.6 & 0.8 & 0.7 & 1.1 & 1.0 & 1.0 & 1.5 \\
\hline FO & 3.8 & 4.5 & 4.0 & 7.2 & 6.1 & 4.4 & 4.1 & 3.4 & 1.7 \\
\hline $\mathrm{Na}_{2} \mathrm{O}$ & 1.2 & 0.8 & 0.6 & 0.5 & 0.6 & 0.6 & 1.6 & 1.0 & 0.8 \\
\hline $\mathrm{MgO}$ & 0.4 & 1.2 & 0.3 & 0.5 & 0.3 & 0.2 & 0.3 & 0.4 & 0.4 \\
\hline $\mathrm{Al}_{2} \mathrm{O}_{3}$ & 0.0 & 0.0 & 0.0 & 0.0 & 0.0 & 0.0 & 0.3 & 0.2 & 0.2 \\
\hline $\mathrm{SiO}_{2}$ & 0.1 & 0.0 & 0.0 & 0.0 & 0.0 & 0.0 & 0.1 & 0.1 & 0.0 \\
\hline Total & 64.0 & 61.4 & 62.9 & 88.0 & 86.7 & 62.9 & 65.7 & 61.7 & 49.0 \\
\hline
\end{tabular}

Notes: Units in wt\%. Locations of most analyses indicated by dots on Plates 1 and 2.

Detrital phosphates:

Sample 128-799A-41X-6, 144-150 cm (Pl. 2, Fig. 2)

Sample 128-799B-45R-1, 130-133 cm (PI, 1, Fig. 8)

Sample 128-799B-45R-2, 38-40 cm (last two analyses = PI. 1, Fig. 7)

Sample 128-799B-55R-1, 139-141 cm (first two analyses = PI. 1, Fig. 6)

Pristine phosphates:

Sample 128-799B-5IX-6, 101-105 cm (Pl. 2, Fig. 3)

Sample 128-799B-6R-1, 106-109 cm (both analyses = PI. 1, Figs. 4, 5)

Sample 128-799B-46R-1, 32-34 cm (last analysis = PI. 1. Fig. 1)

Sample 128-799B-54R-2, 30-32 cm (PI. 1, Fig. 3)

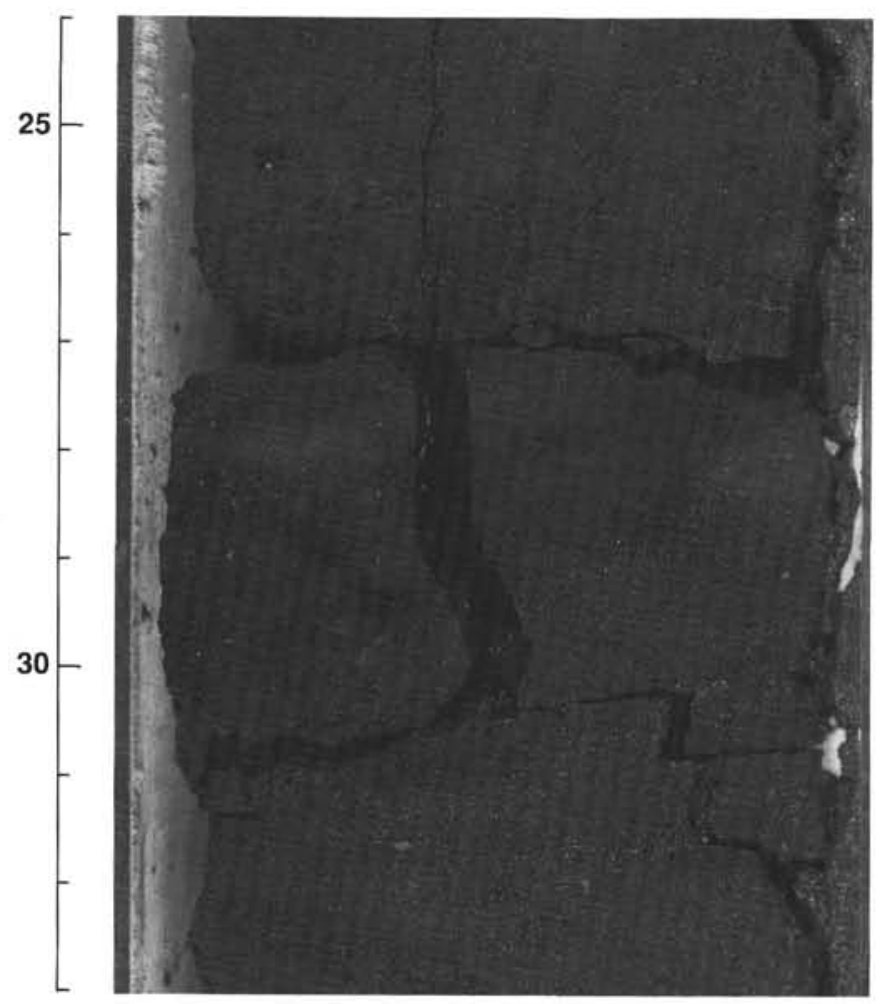

Figure 5. Glauconite-rich interval in Section 128-798B-52X-1, 24-33 cm (lower Pliocene or uppermost Miocene). Note the level of Chondrites-type bioturbation within the glauconite-rich zone that imported less glauconite-rich sediments and Planolites-type bioturbation below the glauconite-rich zone that imported glauconite-rich sediments. with the presence of preexisting phosphate nuclei, which is 150 $\mu \mathrm{mol} / \mathrm{L}$ (Van Cappellen, 1991).

Pore-water fluoride values have been measured using the spectrophotometric procedure with alizarin complexone according to Grasshoff (1976). At Sites 798 and 799, dissolved fluoride profiles are characterized by a downward-decreasing pore-water gradient (Fig. 3). These profiles indicate diffusion from the overlying seawater and removal of fluoride by incorporation into solid phases in the upper $50 \mathrm{~m}$ below sea floor (mbsf). A similar removal has been observed in the Peru margin sediments, an area of extensive phosphate precipitation and accumulation (Froelich et al., 1983). Pore-water profile studies conducted by Froelich et al. (1983) in various sedimentary environments indicate that fluoride uptake occurs only in sediments where phosphate precipitation is taking place; siliceous and calcareous oozes and red clay sediments in the abyssal Pacific show no change in dissolved fluoride concentration with depth.

Using the dissolved fluoride profiles at Sites 798 and 799 and the formulation and assumptions of Froelich et al. (1983), we estimated the rate of fluoride uptake in these sediments as shown in Figure 4, which gives the following values:

$$
\begin{aligned}
& \text { For Site } 798, K_{\mathrm{f}}=4 \times 10^{-5} / \mathrm{yr} \text {. } \\
& \text { For Site } 799, K_{\mathrm{f}}=1.4 \times 10^{-5} / \mathrm{yr} \text {. }
\end{aligned}
$$

These rates are very much slower than those reported by Froelich et al. (1983) for the Peru margin sediments, an observation that is consistent with the recovery of only small amounts of submillimeter-sized solid phosphate particles at both sites. Fluoride is almost completely removed at Site 798 , whereas at Site 799 , fluoride pore-water values stabilize at a level of approximately $20 \mu \mathrm{mol}$. This probably reflects the dependency of fluoride uptake on the availability of dissolved phosphate in pore waters and the presence of solid phosphate particles, which may serve as nuclei for the precipitation of phosphate phases. 
Table 2 (continued).

\begin{tabular}{|c|c|c|c|c|c|c|c|c|c|c|}
\hline & $\begin{array}{c}-799 \mathrm{~B}-45 \mathrm{R}-2, \\
38-40 \mathrm{~cm}\end{array}$ & $\begin{array}{c}-799 \mathrm{~B}-46 \mathrm{R}-2 \\
32-34 \mathrm{~cm}\end{array}$ & $\begin{array}{c}-799 \mathrm{~B}-46 \mathrm{R}-2 \\
32-34 \mathrm{~cm}\end{array}$ & $\begin{array}{c}-799 \mathrm{~B}-46 \mathrm{R} 4-2 \\
32-34 \mathrm{~cm}\end{array}$ & $\begin{array}{c}-799 \mathrm{~B}-46 \mathrm{R}-2, \\
32-34 \mathrm{~cm}\end{array}$ & $\begin{array}{c}-799 \mathrm{~B}-46 \mathrm{R}-2 \\
32-34 \mathrm{~cm}\end{array}$ & $\begin{array}{c}-799 \mathrm{~B}-54 \mathrm{R}-2 \\
30-32 \mathrm{~cm}\end{array}$ & $\begin{array}{c}-799 \mathrm{~B}-55 \mathrm{R}-1 \\
139-141 \mathrm{~cm}\end{array}$ & $\begin{array}{c}-799 \mathrm{~B}-55 \mathrm{R}-1 \\
139-141 \mathrm{~cm}\end{array}$ & $\begin{array}{c}-799 \mathrm{~B}-55 \mathrm{R}-1, \\
139-141 \mathrm{~cm}\end{array}$ \\
\hline $\mathrm{CaO}$ & 18.9 & 26.1 & 29.5 & 39.3 & 25.4 & 43.8 & 32.4 & 32.6 & 29.6 & 38.7 \\
\hline $\mathrm{TiO}_{2}$ & 0.0 & 0.0 & 0.0 & 0.0 & 0.0 & 0.0 & 0.0 & 0.0 & 0.0 & 0.0 \\
\hline $\mathrm{P}_{2} \mathrm{O}_{5}$ & 14.2 & 19.6 & 23.1 & 27.7 & 21.9 & 34.2 & 24.7 & 22.8 & 23.2 & 28.8 \\
\hline $\mathrm{SO}_{3}$ & 5.1 & 2.3 & 2.0 & 2.6 & 2.1 & 1.2 & 2.1 & 2.6 & 2.1 & 2.5 \\
\hline $\mathrm{K}_{2} \mathrm{O}$ & 0.0 & 0.1 & 0.5 & 0.0 & 0.4 & 0.0 & 0.2 & 0.0 & 0.0 & 0.0 \\
\hline $\mathrm{BaO}$ & 0.1 & 0.1 & 0.0 & 0.0 & 0.1 & 0.1 & 0.1 & 0.1 & 0.0 & 0.0 \\
\hline $\mathrm{ClO}$ & 0.8 & 1.5 & 1.1 & 1.0 & 0.6 & 0.5 & 0.3 & 1.0 & 0.4 & 0.8 \\
\hline $\mathrm{FeO}$ & 2.5 & 0.1 & 0.2 & 0.0 & 0.4 & 0.1 & 0.5 & 0.2 & 0.2 & 0.3 \\
\hline $\mathrm{MnO}$ & 1.3 & 1.6 & 1.1 & 1.2 & 0.9 & 1.3 & 0.6 & 1.1 & 1.1 & 0.7 \\
\hline FO & 1.8 & 2.3 & 4.1 & 5.4 & 2.2 & 5.7 & 3.3 & 4.9 & 3.6 & 5.0 \\
\hline $\mathrm{Na}_{2} \mathrm{O}$ & 0.8 & 0.6 & 1.0 & 1.2 & 0.5 & 0.8 & 0.7 & 0.9 & 0.8 & 1.0 \\
\hline $\mathrm{MgO}$ & 0.5 & 0.4 & 0.6 & 0.4 & 0.4 & 0.2 & 0.5 & 0.2 & 0.2 & 0.1 \\
\hline $\mathrm{Al}_{2} \mathrm{O}_{3}$ & 0.2 & 0.4 & 1.8 & 0.0 & 1.5 & 0.0 & 0.1 & 0.3 & 0.2 & 0.0 \\
\hline $\mathrm{SiO}_{2}$ & 0.3 & 2.0 & 6.6 & 0.1 & 3.8 & 0.0 & 3.8 & 2.4 & 1.6 & 0.1 \\
\hline Total & 47.5 & 57.2 & 71.6 & 79.0 & 60.0 & 87.9 & 70.2 & 69.0 & 63.0 & 78.0 \\
\hline
\end{tabular}

\section{GLAUCONITE PARTICLES AT SITE 798 AND 799}

\section{Occurrence}

Glauconite particles were detected in subordinate amounts in almost all samples from Sites 798 and 799. Prominent glauconite-rich layers and horizons, however, are restricted to the following few segments of the cores recovered:

1. Glauconite-rich pockets are present in the core catcher of Core 128-798B-51X, and glauconite-rich layers occur in subjacent intervals of Section 128-798B-52X-1 at 24-30 cm (maximum $40 \%$ glauconite; Pt. 2, Fig. 4, and Fig. 5), 44-55 cm, 75-93 cm, and 134-139 $\mathrm{cm}$ (lower Pliocene or uppermost Miocene).

2. A manganese-rich carbonate layer at Section 128-799A-41X-6, $147-150 \mathrm{~cm}$, encloses a glauconite-rich horizon (10\% glauconite; PI. 2, Fig. 2; upper Miocene).

3. Glauconite-bearing turbiditic deposits occur in lithologic Units IV and V of Hole 799B (maximum 5\%; Pl. 1, Figs. 6-8, and Pl. 2, Fig. 1, and Fig. 6; middle Miocene).

\section{Character of the Glauconite Particles}

In analogy to the phosphate particles, the glauconite particles are classified according to their morphology, association with the embedding sediments and other enclosed sediment particles, as well as their color. We have distinguished between autochthonous and allochthonous particles:

1. Autochthonous glauconite particles are characterized by a uniform and homogeneous appearance, a tendency to have similar color ranges and different grain sizes, and the common presence of irregular, grooved surfaces (Pl. 2, Figs. 2 and 3). Autochthonous glauconites appear in the majority of the investigated samples from both Sites 798 and 799 . They invariably occur in trace amounts, with sizes ranging between 0.025 and $0.4 \mathrm{~mm}$.

2. Allochthonous glauconite particles show a more uniform grainsize distribution. They are fairly well- to well rounded but may bear deep-seated grooves (Pl. 2, Fig. 4; cf. Fischer, 1990). These particles may exhibit different shades of green, varying from pale to a very bright and intense green. They are mostly associated with detrital quartz grains in beds that may display normal grading and sharp and well-defined bases (Pl. 2, Figs. 1 and 4, and Figs. 5 and 6). The observed allochthonous glauconites range in size between 0.05 and $0.5 \mathrm{~mm}$ and are commonly concentrated, so that glauconite values may reach $40 \%-50 \%$ of the total sediment. The most significant allochthonous glauconite-bearing beds occur in Units IV and V of Site 799 and in Unit III of Site 798 (Section 128-798B-52X-1).

\section{Microprobe Analyses}

Cameca SX 50 microprobe analyses on selected glauconite particles reveal large differences in $\mathrm{K}_{2} \mathrm{O}, \mathrm{Al}_{2} \mathrm{O}_{3}$, and especially total iron contents (Table 3 ). In general, total iron contents appear to be rather high (e.g., Odin and Fullagar, 1988). However, Baturin et al. (1989) reported similar high iron values for one glauconite particle derived from the northern flank of the Yamato Rise.

Furthermore, oxide totals may remain substantially below $100 \%$, probably reflecting the presence of hydroxide and interlayered water groups. The low oxide totals are preferentially encountered in allochthonous particles, which exhibit a pale green color. These particles are characterized by lower iron values, a compositional difference that is likely to influence the glauconite color intensity (Deer et al., 1966). They are interpreted as weathered glauconite particles (through prolonged exposure at the sedimentwater interface) enriched in hydroxides and crystal water (cf. Griffin and Lindsley-Griffin, this volume; Odin and Fullagar, 1988).

\section{DISCUSSION AND CONCLUSIONS}

\section{Phosphates}

Pristine phosphates have been encountered throughout the drilled sequences of Sites 798 and 799; they are present at shallow levels, with a first occurrence detected (in the available samples) concurrent to the depth of maximum values of pore-water phosphate (approximately 25-30 mbsf at Site 798). The pore-water gradients of fluoride and phosphate indicate that the sediments between 30 and $50 \mathrm{mbsf}$ are most appropriate for the present formation of francolite at both sites. This is below the sulfate-reduction zone, in the zone of methanogenesis (Ingle, Suyehiro, von Breymann et al., 1990).

The near-zero pore-water values of fluoride below $100 \mathrm{mbsf}$ at Site 798 suggests that this anion is the limiting element in the formation of francolite at Site 798. This is less clear at Site 799, where the generally lower values of pore-water phosphate appear to balance those of pore-water fluoride. At any rate, the ambient geochemical conditions limit and have limited the process of phosphogenesis to the formation of subordinate amounts of mostly submillimeter-sized phosphates. In addition, the high and rather continuous sediment-accumulation rates of approximately 5 to 20 $\mathrm{cm} / 1000$ yr (Ingle, Suyehiro, von Breymann et al., 1990) did not permit phosphates at the here described sites to be recycled and to accrete additional generations of phosphate, once they had formed (Föllmi, 1990; Föllmi and Garrison, 1991).

Detrital phosphates encountered in Hole 799B are most probably derived from the Yamato and Kita-Yamato banks, which flank the Kita-Yamato Trough of Site 799 (Ingle, Suyehiro, von Breymann et 
A

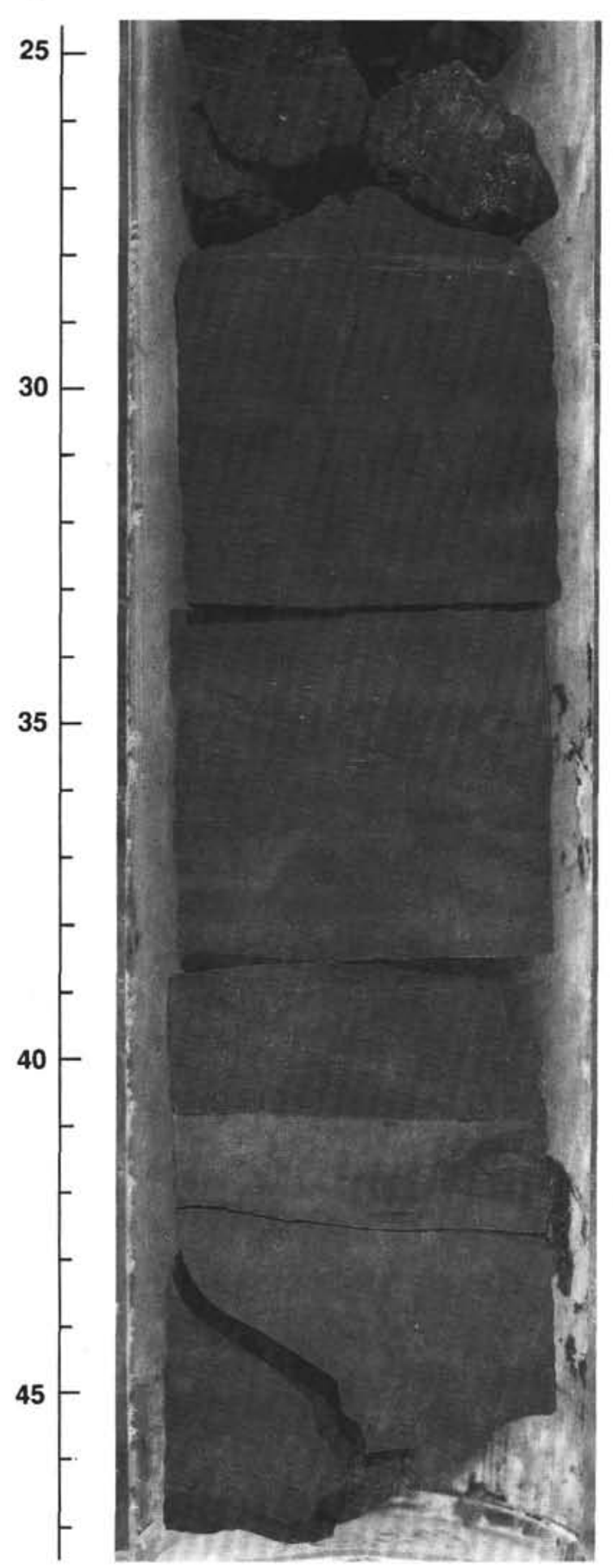

B

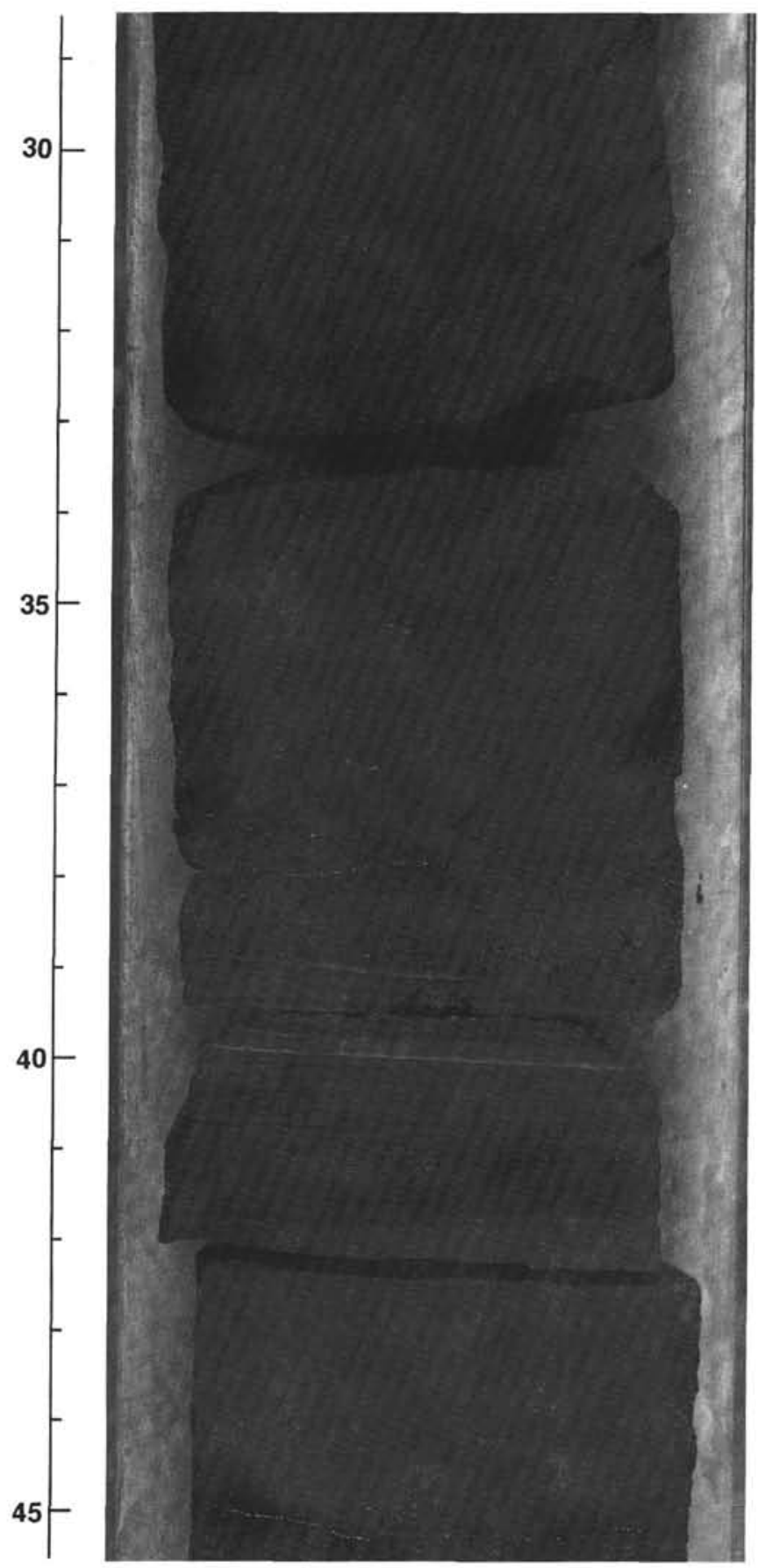

Figure 6. Glauconite-bearing sandy and silty turbidites intercalated in laminated- to weakly bioturbated porcellanites in the upper middle Miocene sequence of Hole 799B (Unit IV). The coarse and dark particles at and near the base of the turbiditic deposits represent glauconites. A. Section 128-799B-40R-1, 26-46 cm; B. Section 128-799B-45R-2, 29-45 cm.

al., 1990). At the northern flank of the Yamato Bank, phosphates of late Miocene age have been dredged (Barash, 1986; Bersenev et al., 1990). The detrital phosphatic particles present at Site 799 are middle Miocene in age and indicate that the bank tops may have functioned as sites of phosphogenesis during a major part of the Miocene.

\section{An Estimate of the Importance of the Japan Sea as a Phosphorus Sink}

The values of total phosphate in the sediments, as detected by $\mathrm{X}$-ray fluorescence and bulk chemical analyses, do not vary significantly and average 0.179 wt $\%$ of total phosphorus (mean value of 


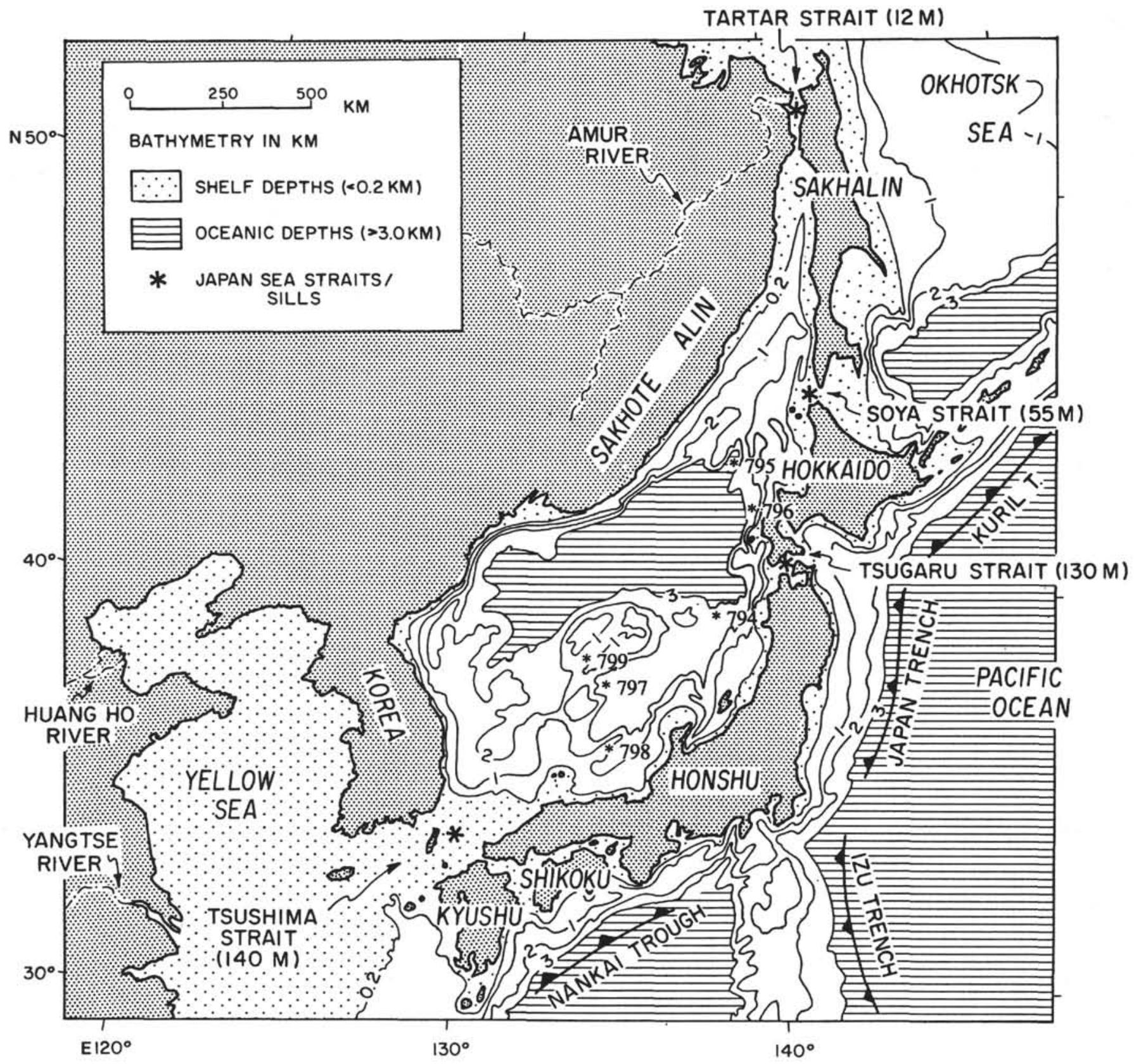

Figure 7. Map of the Japan Sea showing Ocean Drilling Program Leg 127 Sites (794-797) and Leg 128 Sites (794, 798, 799). From Ingle, Suyehiro, von Breymann, et al. (1990).

Table 1). If we extrapolate this value to the entire area of the Japan Sea and take it as a valid mean for the Neogene and Pleistocene, and if we further assume a mean overall sediment-accumulation rate of 4 $\times 10^{-3} \mathrm{~g} / \mathrm{cm} 2 \cdot \mathrm{yr}$ (at the lower limit of mean sediment-accumulation rates estimated at all drilled sites; based upon mean dry bulk densities; Ingle, Suyehiro, von Breymann, et al., 1990; Tamaki, Pisciotto, Allan, et al., 1990) and a seafloor area of approximately $1.008 \times 10^{6} \mathrm{~km}^{2}$ (Hidaka, 1966), approximately $7.2 \times 10^{10} \mathrm{~g} \mathrm{P}_{\text {total }}$ would have been transferred into the sediments of the Japan Sea per year. This estimated rate corresponds to approximately $0.3 \%$ of the estimated global rate of phosphorus delivered into sediments per year $\left(=2.2 \times 10^{13} \mathrm{~g}\right.$ $\mathrm{P}_{\text {total }}$ per year; Mackenzie et al. in press). The surface area of the Japan Sea is approximately $0.27 \%$ of the total ocean surface area $(3.62 \times$ $10^{14} \mathrm{~m}^{2}$ ); and thus the phosphorus buried in the Japan Sea is of the same magnitude as the global flux.

\section{Present Sources of Phosphorus to the Japan Sea}

One important source of phosphorus to the present Japan Sea is the Tshushima Current, a branch of the Kuroshio Current that enters the Japan Sea through the Tshushima Strait, between Korea and Japan. The deepest point in the Tshushima Strait is $140 \mathrm{mbsl}$ and large areas are well above $100 \mathrm{mbsl}$ (Figs. 7 and 8). This current is the sole carrier of Pacific water into the Japan Sea as the input via the Tartar Strait between Siberia and Sakhalin is negligible (Hidaka, 1966). Approximately $6 \times 10^{6} \mathrm{~m}^{3}$ of water per second currently enters the Japan Sea via the Tshushima Current (Tanioka, 1968), with an annual mean content of phosphorus ranging between $0.3 \mu \mathrm{g} / \mathrm{L}$ in the surface waters and $0.4 \mu \mathrm{g} / \mathrm{L}$ for $100 \mathrm{mbsl}$ (Akiyama, 1968). By assuming an average value of $0.35 \mu \mathrm{g} / \mathrm{L}$, we estimate that approximately $6.6 \times 10^{10} \mathrm{~g} \mathrm{P}_{\text {total }}$ enter the Japan Sea per year from the Pacific Ocean. This value is not 
Table 3. Microprobe analyses of selected glauconite particles.

\begin{tabular}{|c|c|c|c|c|c|c|c|c|c|}
\hline & $\begin{array}{c}-798 \mathrm{~B}-51 \mathrm{X}-6 \\
101-105 \mathrm{~cm}\end{array}$ & $\begin{array}{c}-798 \mathrm{~B}-51 \mathrm{X}-6 \\
101-105 \mathrm{~cm}\end{array}$ & $\begin{array}{c}-798 \mathrm{~B}-52 \mathrm{X}-1 \\
27-29 \mathrm{~cm}\end{array}$ & $\begin{array}{c}-798 \mathrm{~B}-52 \mathrm{X}-1 \\
27-29 \mathrm{~cm}\end{array}$ & $\begin{array}{c}-798 \mathrm{~B}-52 \mathrm{X}-1 \\
79-85 \mathrm{~cm}\end{array}$ & $\begin{array}{c}-798 \mathrm{~B}-52 \mathrm{X}-1 \\
79-85 \mathrm{~cm}\end{array}$ & $\begin{array}{c}-799 \mathrm{~A}-41 \mathrm{X}-6 . \\
144-150 \mathrm{~cm}\end{array}$ & $\begin{array}{c}-799 A-41 X-6 \\
144-150 \mathrm{~cm}\end{array}$ & $\begin{array}{c}-799 A-41 X-6, \\
144-150 \mathrm{~cm}\end{array}$ \\
\hline $\mathrm{CaO}$ & 0.0 & 0.1 & 0.0 & 0.0 & 0.0 & 0.1 & 0.1 & 0.1 & 0.1 \\
\hline $\mathrm{TiO}_{2}$ & 0.3 & 0.5 & 0.4 & 0.2 & 0.2 & 0.1 & 0.2 & 0.1 & 0.2 \\
\hline $\mathrm{P}_{2} \mathrm{O}_{5}$ & 0.2 & 0.1 & 0.1 & 0.0 & 0.1 & 0.0 & 0.0 & 0.0 & 0.1 \\
\hline $\mathrm{K}_{2} \mathrm{O}$ & 6.9 & 4.0 & 6.5 & 0.5 & 6.7 & 1.9 & 2.0 & 1.9 & 4.3 \\
\hline $\mathrm{BaO}$ & 0.6 & 1.0 & 0.7 & 0.3 & 0.4 & 0.2 & 0.3 & 0.3 & 0.5 \\
\hline $\mathrm{Cr}_{2} \mathrm{O}$ & 0.1 & 0.1 & 0.1 & 0.0 & 0.1 & 0.0 & 0.1 & 0.1 & 0.1 \\
\hline $\mathrm{Fe}_{2} \mathrm{O}$ & 25.2 & 19.1 & 24.7 & 1.1 & 23.2 & 4.7 & 18.0 & 17.7 & 20.9 \\
\hline $\mathrm{MnO}$ & 0.1 & 0.1 & 0.1 & 0.1 & 0.0 & 0.0 & 0.3 & 0.3 & 0.3 \\
\hline $\mathrm{Na}_{2} \mathrm{O}$ & 0.2 & 1.2 & 0.2 & 0.6 & 0.2 & 0.7 & 0.1 & 0.1 & 0.1 \\
\hline $\mathrm{Al}_{2} \mathrm{O}$ & 5.4 & 7.3 & 5.6 & 2.8 & 6.4 & 4.2 & 3.4 & 3.5 & 3.6 \\
\hline $\mathrm{MgO}$ & 4.0 & 3.8 & 3.8 & 0.6 & 3.9 & 2.8 & 4.8 & 5.1 & 4.8 \\
\hline $\mathrm{SiO}_{2}$ & 54.6 & 56.5 & 55.2 & 56.3 & 57.1 & 34.5 & 48.9 & 47.1 & 53.6 \\
\hline Total & 97.5 & 93.5 & 97.3 & 62.7 & 98.4 & 49.2 & 78.0 & 76.3 & 88.5 \\
\hline
\end{tabular}

Units in wt\%. Locations of most analyses indicated by dots on Plates 1 and 2

Autochthone glauconites:

Sample 128-798B-51X-6, 101-105 cm (first analysis = large particle at the base of Pl. 2, Fig. 3; second analysis small particle in the middle of Pl. 2, Fig. 3)

Sample 128-799A-41X-6, 144-150 cm (first two analyses = large particle in the lower middle of Pl. 2, Fig. 2; last analysis = small particle in lower right of Pl. 2, Fig. 2)

Allochthonous glauconites:

Sample 128-798B-52X-1, 27-29 cm (first analysis = upper particle in PI. 2, Fig. 4; second analysis lower particle in P1. 2, Fig. 4);

Sample 128-799B-45R-1, 130-133 cm (PI. 1, Fig. 6);

Sample 128-799B-45R-2, 38-40 cm (PI. 1, Fig. 7);

Sample 128-799B-55R-1, 139-141 cm (both analyses comparable to particle in PI. 1. Fig. 8)

significantly different from our estimated value of $7.2 \times 10^{10} \mathrm{~g} \mathrm{P}$ buried in the Japan Sea sediments per year.

We have estimated the volume of water leaving the Japan Sea via the Soya Strait (Figs. 7 and 8 ) to be $3.1 \times 10^{6} \mathrm{~m}^{3} / \mathrm{s}$ based on an average velocity of $0.7 \mathrm{kt}$ and estimates of average sill width and depth of 36.9 $\mathrm{km}$ and $27 \mathrm{~m}$, respectively (Hikada, 1966). Similarly, a value of 4.2 $\times 10^{5} \mathrm{~m}^{3} / \mathrm{s}$ of water leaving the Japan Sea via the Tshugaru Strait (Figs. 7 and 8 ) is based on an average velocity of $1 \mathrm{kt}$ and sill width- and depth-approximated values of $16 \mathrm{~km}$ and $60 \mathrm{~m}$ (Sugiura, 1959). The phosphorus contents of the surface waters leaving the Japan Sea are somewhat higher than those of the incoming waters of the Tshushima Current, and range between 0.38 and $0.43 \mu \mathrm{g} / \mathrm{L}$ for the Tshugaru Strait and $0.43 \mu \mathrm{g} / \mathrm{L}$ for the Soya Strait (Akima, 1968). The amount of phosphorus exported via the Tshugaru and Soya Straits $\left(5.3 \times 10^{9} \mathrm{~g}\right.$ $\mathrm{P} / \mathrm{yr}$ and $3.9 \times 10^{10} \mathrm{~g} \mathrm{P} / \mathrm{yr}$ ) is estimated to be approximately $66 \%$ of the phosphorus supplied by the Tshushima Strait (Table 4).
These values suggest that - as a very crude estimate-approximately $34 \%$ of the phosphorus presently imported by the Tshushima Current remains in the Japan Sea. The rest of the phosphorus buried in the sediments of the Japan Sea may be delivered by rivers. The cold waters of the southward-flowing Liman Current, derived from the northernmost part of the Japan Sea and carrying waters of the Amur River, contain approximately $0.4-1.6 \mu \mathrm{g} \mathrm{P} / \mathrm{L}$ (Ohwada and Yamamoto, 1966). The total southward flow is roughly estimated to be $1.8 \times 10^{6} \mathrm{~m}^{3} / \mathrm{s}$, based upon a width of $114 \mathrm{~km}$, an average depth of $120 \mathrm{~m}$, and an average velocity of $0.3 \mathrm{kt}$ (Hikada, 1966). Assuming an average value of $1 \mu \mathrm{g} \mathrm{P} / \mathrm{L}$, we conclude that $5.7 \times 10^{10} \mathrm{~g} \mathrm{P}_{\text {total }}$ per year are delivered by the Liman current system. Neglecting the rest of the river input into the Japan Sea, the phosphate balance of the present-day Japan Sea can be summarized in Table 4.

Inspite of the crudeness of these estimates, the input and output rates of phosphorus for the present-day Japan Sea are well balanced.

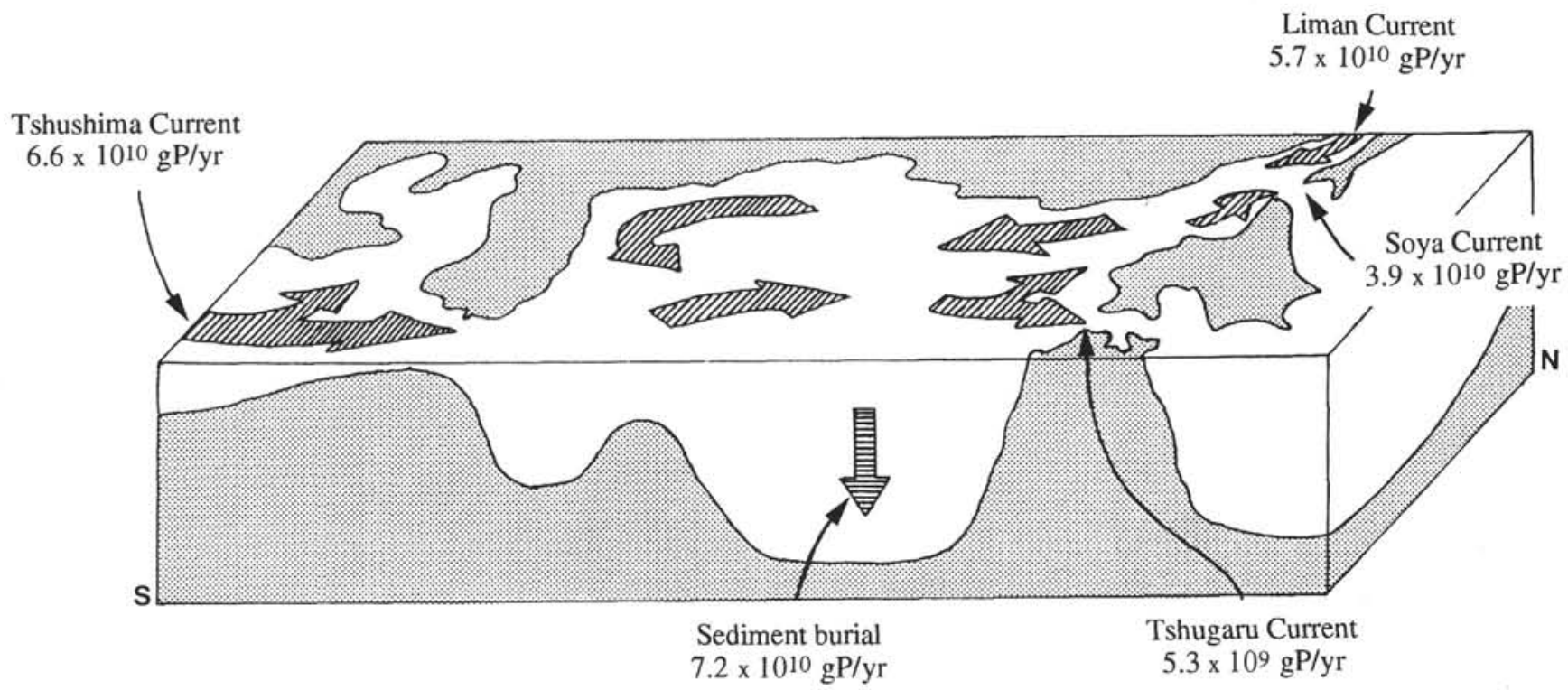

Figure 8. Schematic illustration of shallow circulation in the modern Japan Sea. Estimates of phosphorus transfer rates are indicated (cf. Table 4). Modified from Oba (1983) and Ingle, Suyehiro, von Breymann, et al. (1990). 
Table 3 (continued).

\begin{tabular}{lcccc}
\hline & $\begin{array}{c}-799 \mathrm{~B}-45 \mathrm{R}-1, \\
130-133 \mathrm{~cm}\end{array}$ & $\begin{array}{r}-799 \mathrm{~B}-45 \mathrm{R}-2, \\
38-40 \mathrm{~cm}\end{array}$ & $\begin{array}{r}-799 \mathrm{~B}-55 \mathrm{R}-1, \\
139-141 \mathrm{~cm}\end{array}$ & $\begin{array}{r}-799 \mathrm{~B}-55 \mathrm{R}-1, \\
139-141 \mathrm{~cm}\end{array}$ \\
\hline $\mathrm{CaO}$ & 0.1 & 0.4 & 0.4 & 0.1 \\
$\mathrm{TiO}_{2}$ & 0.2 & 0.3 & 0.0 & 0.4 \\
$\mathrm{P}_{2} \mathrm{O}_{5}$ & 0.0 & 0.1 & 0.1 & 0.1 \\
$\mathrm{~K}_{2} \mathrm{O}$ & 1.8 & 4.2 & 11.5 & 2.9 \\
$\mathrm{BaO}$ & 0.3 & 0.6 & 0.0 & 0.8 \\
$\mathrm{Cr} \mathrm{O}_{2}$ & 0.0 & 0.0 & 0.0 & 0.1 \\
$\mathrm{Fe}_{2} \mathrm{O}$ & 2.0 & 11.8 & 0.2 & 7.4 \\
$\mathrm{MnO}^{\mathrm{NaO}}$ & 0.1 & 0.2 & 0.0 & 0.3 \\
$\mathrm{Al}_{2} \mathrm{O}$ & 0.2 & 0.1 & 1.3 & 0.5 \\
$\mathrm{MgO}^{\mathrm{O} O}$ & 7.2 & 8.6 & 16.2 & 13.9 \\
$\mathrm{SiO}_{2}$ & 2.9 & 5.9 & 0.1 & 8.3 \\
$\mathrm{Total}^{6.6}$ & 82.3 & 50.1 & 67.8 & 50.0 \\
& & 82.4 & 97.7 & 84.8 \\
\hline
\end{tabular}

Table 4. Estimate of phosphorus balance in the Japan Sea.

\begin{tabular}{|c|c|c|c|c|}
\hline \multicolumn{5}{|c|}{ Import of phosphorus into the Japan Sea } \\
\hline & $\begin{array}{l}\text { Maximum sill } \\
\text { depth (mbsl) }\end{array}$ & $\begin{array}{l}\text { Water flow } \\
\left(\mathrm{m}^{3} / \mathrm{s}\right)\end{array}$ & $\begin{array}{l}\text { Average phosphate } \\
\text { content }(\mu \mathrm{g} / \mathrm{L})\end{array}$ & $\begin{array}{c}\text { Phosphate flux } \\
\text { (g P/yr) }\end{array}$ \\
\hline Tshushima C. & 120 & ${ }^{2} 6.0 \times 10^{6}$ & b 0.35 & $6.6 \times 10^{10}$ \\
\hline Liman Current & & ${ }^{9} 1.8 \times 10^{6}$ & ${ }^{d} 1.0$ & $5.7 \times 10^{10}$ \\
\hline Total & & & & $1.2 \times 10^{11}$ \\
\hline \multicolumn{5}{|c|}{ Export of phosphorus } \\
\hline & $\begin{array}{l}\text { Maximum sill } \\
\text { depth (mbsl) }\end{array}$ & $\begin{array}{l}\text { Water flow } \\
\left(\mathrm{m}^{3} / \mathrm{s}\right)\end{array}$ & $\begin{array}{l}\text { Average phosphate } \\
\text { content }(\mu \mathrm{g} / \mathrm{L})\end{array}$ & $\begin{array}{l}\text { Phosphate flux } \\
\text { (g P/yr) }\end{array}$ \\
\hline Tshugaru $C$. & 130 & ${ }^{c} 4.2 \times 10^{5}$ & ${ }^{b} 0.4$ & $5.3 \times 10^{9}$ \\
\hline Soya Current & 55 & $3.1 \times 10^{6}$ & b 0.4 & $3.9 \times 10^{10}$ \\
\hline 'Sedimentation & & & & $7.2 \times 10^{10}$ \\
\hline Total & & & & $1.1 \times 10^{11}$ \\
\hline
\end{tabular}

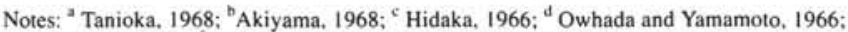
${ }^{e}$ Sugiura, 1959: ${ }^{f}$ Extrapolated from sediments of different ages, this study.

Changes in these values through geological time may be induced by a decrease in the riverine input of the Amur River during periods of glaciation, or by a decrease in the Tshushima-current input during sea-level lowstands.

The measured $\mathrm{P}_{\text {org }} / \mathrm{P}_{\text {inorg }}$ ratios in the Japan Sea sediments indicate that $36 \%$ of $\mathrm{P}_{\text {toal }}$ is present as "refractory" $\mathrm{P}_{\text {org }}$. This number is in agreement with the $\mathrm{P}_{\mathrm{org}} / \mathrm{P}_{\text {inorg }}$ ratios measured in the deep waters of diverse sites of the Japan Sea (approximately $10 \%-50 \%$ between 100 and $3000 \mathrm{mbsl}$; Yamamoto, 1968). Yamamoto (1968) stated that these values are high compared to those in the western North Pacific. He attributed this to the rapid downward transport of organic phosphorus in the Japan Sea.

\section{Glauconites}

One interesting feature with respect to the glauconite particles described herein is that autochthonous particles are present in almost all investigated samples. This implies that glauconite formation is not limited to shelf and slope areas, but also may occur in the sediments of abyssal plains.

Significant concentrations of glauconite in the Japan Sea abyssal plain sediments, however, are invariably allochthonous and have been derived from adjacent bank tops or shallow shelf areas. These glauconites have been subjected to reworking and concurrent chemical weathering prior to final emplacement, processes that are indicated by the different degrees of color intensity and lowered oxide totals (microprobe analyses) in the mixtures of allochthonous glauconite particles in the lower Pliocene and upper and middle Miocene sequences of Sites 798 and 799.

\section{ACKNOWLEDGMENTS}

We are grateful to the Swiss National Science Foundation (KF) and the USSAC (MvB) for financial support during shipboard participation and consequent shore-based research. We thank Aime Ründal (Zürich) for her assistance at the microprobe, Frowin Pirovino (Zürich) for the skillful preparation of the thin sections, and Chieh Peng (College Station) for assistance with the phosphorus analyses. Craig Glenn (Honolulu) and an anonymous reviewer are thanked for their helpful suggestions and corrections.

\section{REFERENCES}

Akiyama, T., 1968. The distribution of dissolved oxygen and phosphate phosphorus in the adjacent seas of Japan. Oceanogr. Mag., 20:147-172.

Aspila, K. I., Agemian, H., and Chau, A.S.Y., 1976. A semi-automated method for the determination of inorganic, organic and total phosphate in sediments. Analyst, 101:187-197.

Barash, M. S., 1986. The paleoceanographic conditions of formation of the late Miocene phosphorite horizon of the North Yamato Rise (Sea of Japan). Oceanology, 26:721-724.

Baturin, G. N., 1988. Disseminated phosphorus in oceanic sediments-a review. Mar. Geol., 84:95-104.

Baturin, G. N., Novikova, Z. T., and Isayeva, A. B., 1989. Glauconites of the Northern Yamato Rise in the Sea of Japan. Oceanology, 29:74-76.

Berner, R. A., 1980. Early Diagenesis, a Theoretical Approach: Princeton (Princeton Univ. Press).

Berner, R. A., Ruttenberg, K. C., Ingall, E. D., and Rao, J. L., in press. The nature of phosphorus burial in modern marine sediments. In Wollast, R. and MacKenzie, F. T. (Eds.), Interactions of C, N, P, and S Biogeochemical Cycles: Heidelberg (Springer).

Bersenev, I. I., Baturin, G. N., Lelikov, E. P., and Gusev, V. V., 1990 Neogene phosphorites of the Sea of Japan. In Burnett, W. C., and Riggs, S. R. (Eds.), Phosphate Deposits of the World (Vol. 3): Neogene to Modern Phosphorites: Cambridge (Cambridge Univ. Press), 167-176.

Cook, P. J., 1984. Spatial and temporal controls on the formation of phosphate deposits. In Nriagu, J. O., and Moore, P. B. (Eds.), Phosphate Minerals: Heidelberg (Springer), 242-274.

Deer, W. A., Howie, R. A., and Zussman, J., 1966. An Introduction to the Rock-Forming Minerals: London (Longman Group).

Fischer, H., 1990. Glauconite formation: discussion of the terms authigenic, perigenic, allogenic, and meta-allogenic. Eclogae Geol. Helv., 83:1-6.

Föllmi, K. B., 1990. Condensation and phosphogenesis; example of the Helvetic mid-Cretaceous (northern Tethyan margin). In Notholt, A.J.G., and Jarvis, I. (Eds.), Phosphorite Research and Development. Geol. Soc. Spec. Publ. London, 52:237-252.

Föllmi, K. B., and Garrison, R. E., 1991. Phosphatic sediments, ordinary or extraordinary deposits? The example of the Miocene Monterey Formation (California). In Müller, D. W., McKenzie, J. A., and Weissert, H. (Eds.), Controversies in Modern Geology: London (Academic Press), 55-84.

Föllmi, K. B., Garrison, R. E., and Grimm, K. A., 1991. Stratification in phosphatic sediments: illustrations from the Neogene of Central California. In Einsele, G., Ricken, W., and Seilacher, A. (Eds.), Cycles and Events in Stratigraphy: Heidelberg (Springer), 492-507.

Froelich, P. N., Bender, M. L., Luedtke, N. A., Heath, G. R., and De Vries, T., 1982. The marine phosphorus cycle. Am. J. Sci., 282:474-511.

Froelich, P. N., Kim, K. H., Jahnke, R., Burnett, W. C., Soutar, A., and Deakin, M., 1983. Pore water fluoride in Peru continental margin sediments: uptake from seawater. Geochim. Cosmochim. Acta, 47:1605-1612.

Gieskes, J. M., and Peretsman, G., 1986. Water chemistry procedures aboard Joides Resolution-some comments. ODP Tech. Note, 5.

Grasshoff, K., 1976. Methods of Seawater Analysis: New York (Weinhem).

Hidaka, K., 1966. Japan Sea. In Fairbridge, R. W. (Ed.), Encyclopedia of Oceanography: New York (Reinhold), 417-424.

Ingall, E. D., Schroeder, P. A., and Berner, R. A., 1990. The nature of organic phosphorus in marine sediments: new insights from ${ }^{31} \mathrm{P}$ NMR. Geochim. Cosmochim. Acta, 54:2617-2620. 
Ingle, J. C., Jr., Suyehiro, K., von Breymann, M. T., et al., 1990. Proc. ODP, Init. Repts., 128: College Station, TX (Ocean Drilling Program).

Krajewski, K. P., 1984. Early diagenetic phosphate cements in the Albian condensed glauconitic limestone of the Tatra Mountains, western Carpathians. Sedimentology, 31:443-470.

Mackenzie, F. T., Ver, L. M., Sabine, C., and Lane, M., in press. C, N, P, S global biochemical cycles and modeling of global change. In Wollast, R., and MacKenzie, F. T. (Eds.), Interactions of $C, N, P$, and S Biogeochemical Cycles: Heidelberg (Springer).

Nathan, Y., 1984. The mineralogy and geochemistry of phosphorites. In Nriagu, J. O., and Moore, P. B. (Eds.), Phosphate Minerals: Heidelberg (Springer), 275-291.

Oba, T., 1983. Paleoenvironment of the Sea of Japan since the last glacial epoch. Gekkan Chikyu, 5:38-46. (in Japanese)

Odin, G. S., and Fullagar, P. D., 1988. Geological significance of the glaucony facies. In Odin, G. S. (Ed.), Green Marine Clays: Amsterdam (Elsevier), 295-332.

Odin, G. S., and Matter, A., 1981. De glauconarium origine. Sedimentology, 28:611-641.

Ohwada, M., and Yamamoto, K., 1966. Some chemical elements in the Japan Sea. Oceanogr. Mag., 18:33-38.

Sugiura, J., 1959. On the currents south off Hokkaido in the western north Pacific. Oceanogr. Mag., 11:1-11, 79-97.
Tamaki, K., Pisciotto, K., Allan, J., et al., 1990. Proc. ODP, Init. Repts., 127: College Station, TX (Ocean Drilling Program).

Tanioka, K., 1968. On the east Korean warm current (Tosen warm current). Oceanogr. Mag., 20:31-38.

Van Cappellen, P., 1991. The formation of marine apatite, a kinetic study [Ph.D. dissert.]. Yale University, New Haven.

Van Houten, F. B., and Purucker, M. E., 1984. Glauconitic peloids and chamositic ooids favorable factors, constraints, and problems. Earth-Sci. Rev., 20:211-243.

1985. On the origin of glauconitic and chamositic granules. GeoMar. Lett., 5:47-49.

Yamamoto, K., 1968. The total and organic phosphorus in the Japan Sea. Oceanogr. Mag., 20:39-53.

Date of initial receipt: 12 April 1991

Date of acceptance: 22 November 1991

Ms 127/128B-116 

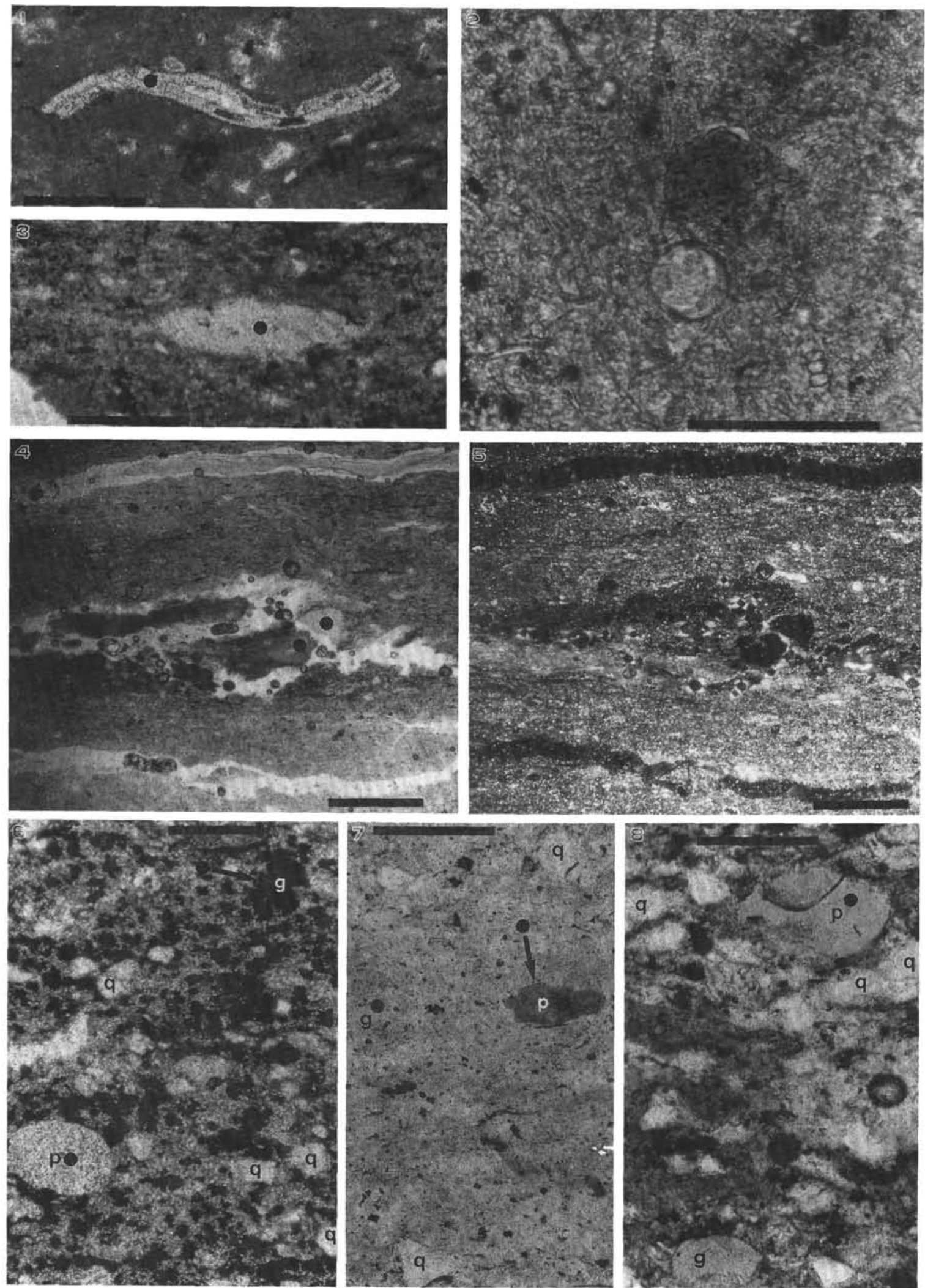

Plate 1. Phosphates at Sites 798 and 799; $p=$ phosphate, $g=$ glauconite, $q=$ quartz. 1. Phosphatized soft-body fossil; Sample 128-799B-46R-2, 32-34 $\mathrm{cm}$. 2. Pristine ( $=$ in situ) phosphate particle in a diatom-rich carbonate bed; Sample 128-798B-38X-5, 68-70 cm. 3. Phosphate lenticle in an organic-rich claystone; Sample 128-799B-54R-2, 30-32 cm. 4. and 5. Phosphate-rich zone associated with a siliceous compaction vein; Sample 128-799B-6R-1, 106-109 cm (5 = crossed nicols). 6. Detrital phosphate particle with a vermiculated texture, associated with quartz and glauconite particles; Sample 128-799B-45R-1, 130-133 cm; 7. Probably allochthonous phosphate particle; Sample 128-799B-45R-2, 38-40 cm. 8. Transported and partly broken phosphate particle, associated with quartz and glauconite particles; Sample 128-799B-55R-1, 139-141 cm. 1, 3, 7, 8: Bar = 0.25 mm; 2: Bar = 0.1 mm; 4, 5, 6: Bar $=1 \mathrm{~mm}$. Location of microprobe analyses indicated by dots (cf. Tables 2 and 3 ). 

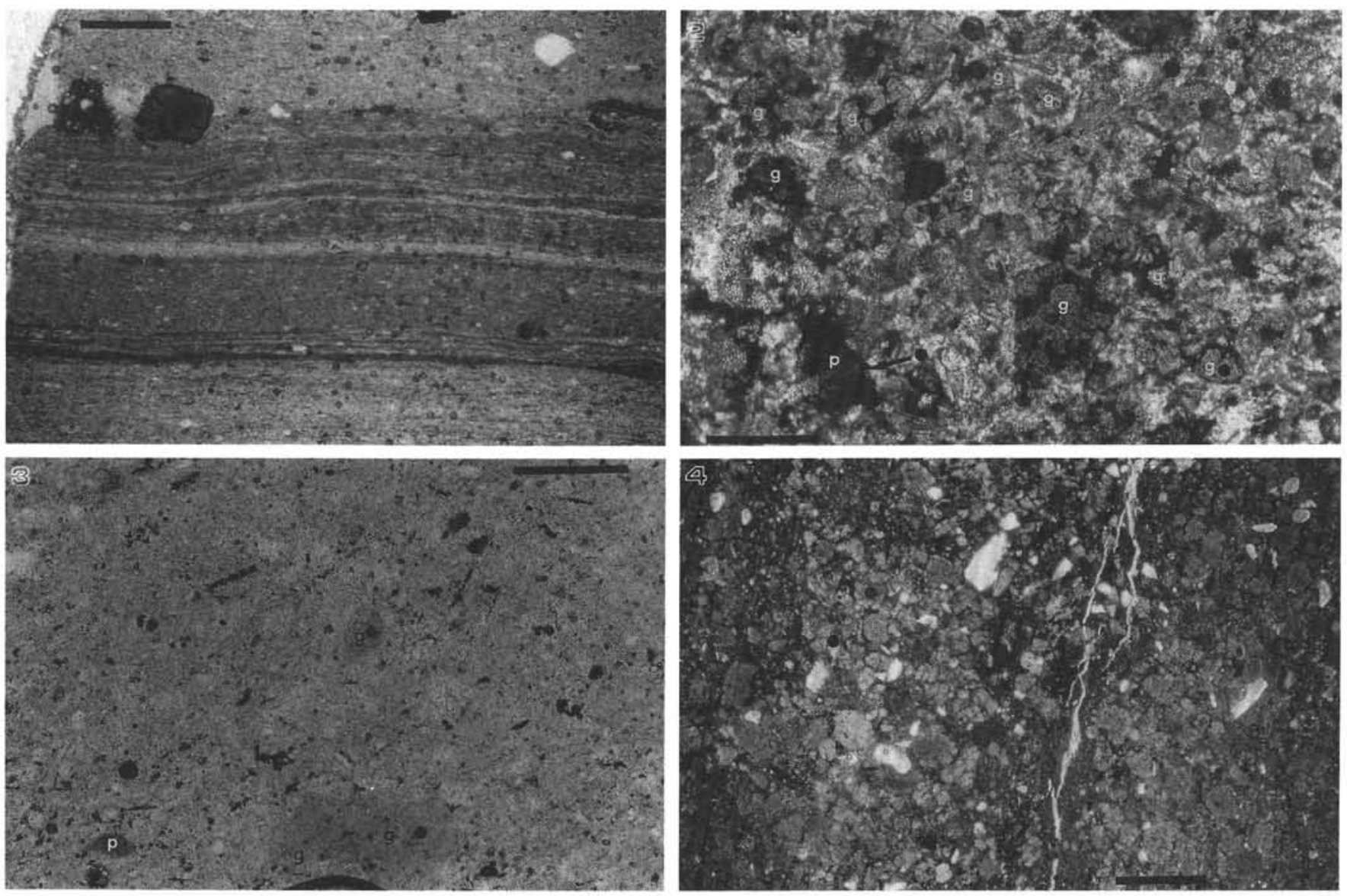

Plate 2. Glauconites at Sites 798 and 799; $\mathrm{p}=$ phosphate, $\mathrm{g}=$ glauconite. 1. Glauconite particle at the base of a thin turbidite layer; Sample 128-799B-42R-1, 46-48 $\mathrm{cm}$. 2. Autochthonous glauconite particles in a diatom-rich pelloidal manganese carbonate bed; Sample $128-799 \mathrm{~A}-41 \mathrm{X}-6,144-150 \mathrm{~cm}$. 3. Autochthonous glauconite particles associated with phosphate particles in a siliceous claystone; Sample 128-798B-51X-6, 101-105 cm. 4. Concentrations of allochthonous glauconite particles; Sample 128-798B-52X-1, 27-29 cm. 1, 4: Bar $=1 \mathrm{~mm} ; 2,3:$ Bar $=0.25 \mathrm{~mm}$. Location of microprobe analyses indicated by dots (cf. Tables 2 and 3 ). 